Egyptian Journal for Aquaculture

P-ISSN: 2090-7877

E-ISSN: 2636-3984

www.eja.journals.ekb.eg/

Enas et al., 2020; 10 (2):43-62

DOI: $10.21608 /$ eja.2020.38241.1030

\title{
Effect of Azolla pinnata and Nannochloropsis oculata on growth performance and immunoresponse of Nile tilapia (Oreochromis niloticus) and its resistance to bacterial infection
}

Enas, M. G. Mansour ${ }^{1}$, Mounes, H. A. M. ${ }^{1}$ and K. M. Ahmed ${ }^{2}$.

1-Department of Limnology, Central laboratory for Aquaculture Research, Abbassa, Agricultural Research Center, Egypt.

2-Fish Production Branch, Department of Animal Production, Faculty of Agriculture, Ain Shams University, Cairo, Egypt.

Received: Aug. 06, 2020; Accepted: Aug.25, 2020 published: 2020 Vol.10 (3):43-62

\section{Abstract}

This experiment aimed to appraise growth performance, hematological and immuno-physiological indices of Nile tilapia when fed on diets in which soybeans were partially replaced by Azolla pinnata or Nannochloropsis oculata. A control diet (basic diet) was tested against 6 practical diets (3 diets partially replaced soybean with Azolla pinnata and 3 diets partially replaced soybean with Nannochloropsis oculata at three different percentages $(2.5,5$ and $7.5 \%)$ The highest values of growth parameters were recorded in $\mathrm{T}_{3}$ (Azolla 5 $\%$ ), followed by $\mathrm{T}_{4}$ (Azolla $7.5 \%$ ), $\mathrm{T}_{5}$ (Nano $2.5 \%$ ), $\mathrm{T}_{7}$ (Nano $7.5 \%$ ), $\mathrm{T}_{6}$ (Nano $5 \%$ ), $\mathrm{T}_{2}$ (Azolla $2.5 \%$ ), and then $\mathrm{T}_{1}$ (negative control). At the end of the experiment, $\mathrm{T}_{4}$ recoded the highest values of Total protein and Globulin while the lowest readings were in $T_{3}$, Albumin lowest value was in $T_{5}$ and the highest one accomplished in $\mathrm{T}_{2}$ with a significant differences between all treatments. For the antioxidant parameters, the negative control $\left(\mathrm{T}_{1}\right)$ recoded the highest MDA value, while had the lowest values of SOD, GPX and Lysozyme. The highest values of (SOD and GPX) accomplished in $\mathrm{T}_{6}$ while the highest value of Lysozyme was recorded in $\mathrm{T}_{4}$. The challenge with A. hydrophila showed that, the highest mortality rate $(80 \%)$ was recorded in control, while the lowest one $(10 \%)$ was recorded in $\mathrm{T}_{3}$ and $\mathrm{T}_{4}$.

Key words: Azolla pinnata, Nannochloropsis oculata, growth performance, Nile tilapia and immunoresponse 


\section{Introduction}

Algae represent one of the unexplored groups of organisms; there are 36,000 known species and more than 200,000 algal species worldwide. Several hundreds of microalgal species have been used as food; however there were less than twenty species are popularly used in aquaculture as feeds (Khan et al., 2018).

Microalgae play an important role in aquatic food chain and are popularly used in rearing of aquatic animals like mollusks, shrimps and fish at different growth stages (Borowitzka 1988). They are required for larvae nutrition during a brief period of life cycle and are used either for direct consumption or indirectly as prepared feed. In most instances, the whole algae is used as feed or feed supplement. Live algae also improve the water quality. Data concerning chemical composition of algae give the basic information of the nutritive potential of the algae biomass (Brown et al., 1997). Consequently, it has a multiple potential to produce highvalued products and there is an urgent need of awareness makes these biomolecules popular in the world to meet the increasing demands with respect to population. Most of these biomolecules are not produced in the animal / human body but termed as essential; therefore, it is highly recommended to make these biomolecules available for food and feed purposes (Yaakob et al., 2014). Nearly all the microalgae are producing unique natural chemicals such as antioxidants, carotenoids, fatty acids, enzymes, polymers, peptides, toxins and sterols (Dahman et al., 2019). The reduction in the fish stocks in the natural sources and decrease in catch led to focusing on producing fish from aquaculture; hence the microalgae was the center of attention in recent years in feed industry as a feed additive due to, it's extremely potent natural antioxidants available and pivotal role in supporting the immune system among other medicinal properties in fending against the detrimental effects of both pathogens and pollutants (Jean-Baptiste Guillerme et al., 2017 and Howe et al. 2006).

Nannochloropsis represents a genus of marine green microalgae with high photosynthetic efficiency and can convert carbon dioxide to storage lipids mainly in the form of triacylglycerols and to the $\omega-3$ long-chain polyunsaturated fatty acid eicosapentaenoic acid (EPA). Recently, Nannochloropsis has always received increasing interest in both research and the public community (Ma et al., 2016) because its ability to synthesize not only neutral lipids for biodiesel production but also Eicosapentaenoic acid (EPA) for functional food (Hoffmann et al., 2010 and Ma et al., 2014). This microalga is an important and additive food source in the commercial breeding of many aquatic animals, especially 
live food organisms such as rotifers, which, in turn, are used to rear the larvae of marine finfish (Durmaz, 2007).

The aquatic free-floating fern; Azolla pinnata belongs to the family Azollaceae, which grows in association with the blue-green algae, Anabaena azollae, and is considered to be a promising feed because of its good nutritive value, the ease of cultivation, and high productivity (Maity and Patra, 2008) and Prabina and Kumar, 2010).

A. pinnata appears as a good source of protein and contains almost all essential amino acids that are superior to wheat bran, maize, offals, etc. (Cherryl et al. 1994 and Basak et al. 2002). Generally, the crude protein content of that plant species is found in the range from $25 \%$ to $30 \%$ in dry matter basis at optimum growth conditions (Basak et al., 2002). Under natural conditions, protein values near $20 \%$ to $22 \%$ are frequent. Therefore, the protein content of A. pinnata is comparable or higher than that of most other aquatic macrophytes. This plant is naturally rich in minerals such as iron, calcium, magnesium, potassium, phosphorus, manganese, etc., apart from appreciable quantities of vitamin A, precursor beta-carotene, and vitamin B12 (Anitha et al., 2016). It is also found that Azolla plants contain some probiotics and biopolymers (Pillai et al. 2002).

A. pinnata is common in most Asian rice fields, ponds, and roadside ditches, and has considerable potential in fish culture. It proliferates at a high rate in natural ponds and, if necessary, for large supply, can be grown with very low cost (Basak $\boldsymbol{e t}$ al., 2002). Azolla production systems where the plant served as an in situ fresh food for the macro phytophagous fish (Cagauan et al. 2000). Azolla pinnata has many benefits such as bio fertilizer, human food, animal and fish feed, as well as medicinal supplements (Mithraja et al., 2011).

A. pinnata as a fresh feed, in combination with a food level of natural feeding, can be beneficial to fish production (Cagauan and Pullin, 1994). Therefore, it could be an excellent inexpensive feed for B. gonionotus. Dried and processed Azolla have been tested as feed ingredient in a number of fish species (e.g., tilapia, carp, etc.) for their effect on growth and yield (Mohanty and Dash, 1995 and Fiogbé et al., 2004).

Therefore, the specific aims of the present study were to examine the effect of (Azolla pinnata and nannocholoropsis oculata) with three different levels on growth performance, hematological and immunophysiological indices of Nile tilapia.

\section{Materials and Methods}


This work was carried out in Limnology Department, Central Laboratory of Aquaculture Research, Abbassa, Sharkia, Egypt, to examine the effect of (Azolla pinnata and nannocholoropsis oculata) partial substitution of Soybean Meal with three different levels / each on growth performance, hematological and immuno-physiological indices of Nile tilapia for 60 days.

\section{The experimental design}

A total of 210 Oreochromis niloticus (L.) juveniles with about $31 \mathrm{~g}$ average initial weight; were randomly allotted in the twenty one aquaria (210 litre / each), cultivation density was ten fish / aquarium reared in seven treatments each of three replicates. $\left(T_{1}\right)$ was a negative control treatment and then six treatments, according to the level of soybeans replacement, either with Azolla Pinnata or Nanochlorpsis oculata as follow: $\mathrm{T}_{2}\left(2.5 \%\right.$ azolla), $\mathrm{T}_{3}\left(5 \%\right.$ azolla), $\mathrm{T}_{4}(7.5 \%$ azolla $), \mathrm{T}_{5}(2.5 \%$ nano), $\mathrm{T}_{6}\left(5 \%\right.$ nano) and $\mathrm{T}_{7}(7.5 \%$ nano). During the experimental period, all fish were fed a pelleted $30 \%$ protein diet twice / day at (09:00 and 13:00 h) five days a week at a rate of $4.5 \%$ of tilapia biomass daily, and two days starvation till the end of the experimental period. The water was partially renewed with new fresh dechlorinated water every 2 days and was aerated by air pumps. Five fish of each aquaria were weighted fortnightly.

\section{Cultivation of Azolla Pinnata}

A. Pinnata was obtained from Agriculture Research Center, then it was grown in concrete ponds ( $5 \mathrm{~m}$ length; $2.5 \mathrm{~m}$ width; $1 \mathrm{~m}$ height). These ponds were drained, cleaned and then refilled with freshwater to a depth of $30 \mathrm{~cm}$. Azolla Pinnata growth was enhanced by supplying $1 \mathrm{~kg}$ chicken manure weekly. Azolla Pinnata was harvested every 14 days with a scoop net, then thoroughly washed with fresh water to remove dirt and debris and then air dried according to Indira et al., (2014).

\section{Cultivation of Nannocholoropsis oculata}

\section{Media and growth conditions}

First, prepare the Fe citrate stock solution by dissolving citrate and ferric ammonium citrate in 1 liter of distilled water. BG-11 medium prepared by adding $900 \mathrm{ml}$ distilled water with $1 \mathrm{ml}$ of the Fe Citrate solution, and then add the remaining components autoclaved where $\mathrm{pH}$ 7.4 Allen and Stanier 1968, and modified by Watanabe et al., 2000.

\section{Average daily gain (ADG)}

Daily gain was estimated according to the following formula: 


$$
A D G=\left(W t_{2-w t_{1}}\right) / t
$$

Where:

$\mathrm{wt}_{1}=$ first fish weight in grams.

wt $2=$ following fish weight in grams.

$\mathrm{t}=$ period in days.

Table (1). Components of BG11 growth media

\begin{tabular}{|c|c|c|}
\hline Component & Stock Solution & Quantity \\
\cline { 1 - 2 } Fe Citrate solution & \multirow{2}{*}{$1 \mathrm{ml}$} \\
\hline Citric acid & $6 \mathrm{~g} / 1$ & \\
\hline Ferric ammonium citrate & $6 \mathrm{~g} / 1$ & \\
\hline $\mathrm{NaNO}_{3}$ & $1.5 \mathrm{~g} / 1$ & $1 \mathrm{ml}$ \\
\hline $\mathrm{K}_{2} \mathrm{HPO}_{4}$ & $39 \mathrm{~g} / 1$ & $1 \mathrm{ml}$ \\
\hline $\mathrm{MgSO}_{4} \cdot 7 \mathrm{H}_{2} \mathrm{O}$ & $75 \mathrm{~g} / 1$ & $1 \mathrm{ml}$ \\
\hline $\mathrm{CaCl}_{2} \bullet 2 \mathrm{H}_{2} \mathrm{O}$ & $27 \mathrm{~g} / 1$ & $1 \mathrm{ml}$ \\
\hline $\mathrm{Na}_{2} \mathrm{CO}_{3}$ & $20 \mathrm{~g} / 1$ & $1 \mathrm{ml}$ \\
\hline $\mathrm{Na}_{2} \mathrm{SiO}_{3} \bullet 9 \mathrm{H}_{2} \mathrm{O}$ & $58 \mathrm{~g} / 1$ & trace metals solution \\
\hline--- & $($ see recipe below) &
\end{tabular}

\section{Trace metals solution}

Table (2). Composition of Trace metal solution (Rippka et al., 1979)

\begin{tabular}{|l|c|}
\hline $\mathrm{H}_{3} \mathrm{BO}_{3}$ & $2.86 \mathrm{~g} / 1$ \\
\hline $\mathrm{MnCl}_{2}$ & $1.81 \mathrm{~g} / 1$ \\
\hline $\mathrm{ZnSO}_{4} \cdot 7 \mathrm{H}_{2} \mathrm{O}$ & $0.22 \mathrm{~g} / 1$ \\
\hline $\mathrm{CuSO}_{4} \cdot 5 \mathrm{H}_{2} \mathrm{O}$ & $0.079 \mathrm{~g} / 1$ \\
\hline $\mathrm{Na}_{2} \mathrm{MoO}_{4} \cdot 2 \mathrm{H}_{2} \mathrm{O}$ & $0.39 \mathrm{~g} / 1$ \\
\hline $\mathrm{Co}\left(\mathrm{NO}_{3}\right) 2 \cdot 6 \mathrm{H}_{2} \mathrm{O}$ & $0.049 \mathrm{~g} / 1$ \\
\hline
\end{tabular}

The culture injection with microalga N. oculata and incubated at $30 \pm$ $2^{\circ} \mathrm{C}$ under continuous illumination produced by white fluorescent light (3000 lux) and constant aeration for 16 days.

\section{Nannochloropsis oculata mass culture and harvesting}


For obtaining 100 liter of algae, filled glass aquaria with 100 liters distilled water, $3.335 \mathrm{~kg}$ super phosphate was added and left for 24 hours until it was completely dissolved, then $0.830 \mathrm{~kg}$ Urea and $11.1 \mathrm{~kg}$ ammonium sulfate were added until complete dissolving. The culture injected with two liter from pure stock cultures of Nannocholoropsis oculata was prepared in BG11. Aquarium incubated at $30 \pm 2{ }^{\circ} \mathrm{C}$ under continuous illumination produced by white fluorescent light (3000 lux) and constant aeration for 16 days. The algal cells were harvested by filtering the aquaria by using $100 \mu$ diameter nylon gauze sheets). The $N$. oculata algal cells were dried in an oven at $60^{\circ} \mathrm{C}$ and grounded by using an electric mill.

Table (3). The proximate composition of the experimental diets

\begin{tabular}{|l|c|c|c|c|c|c|c|}
\hline Ingredients & $\begin{array}{c}\text { Control } \\
\text { (T1) }\end{array}$ & T2 & T3 & T4 & T5 & T6 & T7 \\
\hline Yellow Corn & 28 & 26 & 24 & 21.5 & 25.5 & 22 & 18.5 \\
\hline Soybean meal (48 \%) & 40 & 39 & 38 & 37 & 39 & 38 & 37 \\
\hline Fish meal (65 \%) & 9 & 9 & 9 & 9 & 9 & 9 & 9 \\
\hline Wheat middling & 12 & 14 & 16 & 18.5 & 14.5 & 18 & 21.5 \\
\hline Rice bran & 7 & 7 & 7 & 7 & 7 & 7 & 7 \\
\hline N. oculata & 0 & 0 & 0 & 0 & 1 & 2 & 3 \\
\hline Azolla Pinnata & 0 & 1 & 2 & 3 & 0 & 0 & 0 \\
\hline Vegetable Oil & 1 & 1 & 1 & 1 & 1 & 1 & 1 \\
\hline Fish Oil & 1 & 1 & 1 & 1 & 1 & 1 & 1 \\
\hline Premix & 1 & 1 & 1 & 1 & 1 & 1 & 1 \\
\hline Salt & 1 & 1 & 1 & 1 & 1 & 1 & 1 \\
\hline Crude Protein \% & $\mathbf{3 0}$ & $\mathbf{3 0}$ & $\mathbf{3 0}$ & $\mathbf{3 0}$ & $\mathbf{3 0}$ & $\mathbf{3 0}$ & $\mathbf{3 0}$ \\
\hline Ether Extract \% & $\mathbf{5 . 7 4}$ & $\mathbf{5 . 7 6}$ & $\mathbf{5 . 7 7}$ & $\mathbf{5 . 7 8}$ & $\mathbf{6 . 0 2}$ & $\mathbf{6 . 3}$ & $\mathbf{6 . 5 8}$ \\
\hline Crude Fiber \% & $\mathbf{3 . 1 8}$ & $\mathbf{3 . 3}$ & $\mathbf{3 . 4 3}$ & $\mathbf{3 . 5 6}$ & $\mathbf{3 . 1 9}$ & $\mathbf{3 . 2}$ & $\mathbf{3 . 2 1}$ \\
\hline NFE \% & $\mathbf{6 1 . 0 8}$ & $\mathbf{6 0 . 9 4}$ & $\mathbf{6 0 . 8}$ & $\mathbf{6 0 . 6 6}$ & $\mathbf{6 0 . 7 9}$ & $\mathbf{6 0 . 5}$ & $\mathbf{6 0 . 2 1}$ \\
\hline Water quality & & & & & & \\
\hline
\end{tabular}

Water quality parameters

Water samples were collected fortnightly from each aquarium to monitor different water quality parameters. Water temperature and dissolved oxygen were measured in site using a portable oxygen meter (Jenway, London, UK). The $\mathrm{pH}$ values were measured using a $\mathrm{pH}$-meter (Digital Mini-pH Meter, model 55, Fisher Scientific, Denver, CO, USA). 
The unionized ammonia $\left(\mathrm{NH}_{3}\right)$ was measured using a Multi-parameters Ion Analyzer (HANNA Instruments, Rhode Island, USA).

\section{Serum biochemical and immunological parameters}

Samples were taken twice, after one and two months of the experimental period. Fish were fasted for $24 \mathrm{~h}$ prior to sampling. Ten O. niloticus were taken from each treatment randomly and anaesthetized with benzocaine $(80 \mathrm{mg} / \mathrm{l})$. Fish blood samples were collected from the caudal vein by heparinized sterile syringe. Plasma was obtained by centrifugation of blood at 5000xg for $15 \mathrm{~min}$; the separated plasma was stored at $-20{ }^{\circ} \mathrm{C}$ for further assays.

\section{Biochemical parameters}

All investigated serum parameters such as alanine aminotransferase (ALT), aspartate aminotransferase (AST), total proteins (TP) and albumin (ALB) were measured using reagent kits supplied by (Biomed Diagnostic, Egypt) spectrophotometric commercial kits, according to the manufacturer's instructions; while globulin was calculated according to Busher (1990).

\section{Plasma antioxidant assay}

The activities of antioxidant enzymes in fish plasma were measured by diagnostic reagent kits; according to the manufacturer's instructions (My BioSource Inc., San Diego, California, USA). Malondialdehyde (MDA) level was analyzed by thiobarbituric acid method (Ohkawa et al., 1979). Activities of superoxide dismutase (SOD), catalase (CAT), and glutathione peroxidase (GPx) were measured spectrophotometrically according to methods described by McCord and Fridovich (1969), Aebi (1984) and Paglia and Valentine (1967), respectively.

\section{Serum lysozyme activity}

Lysozyme concentration was measured according to the method of Schltz (1987), whereas Lysoplate was prepared as $1 \%$ agarose in 0.067 M PBS at pH 6.3. When the suspension (Micrococcus lysodeikticus) was added and mixed well to form a homologous mixture. The mixture was poured in Petri dish at thickness $4 \mathrm{~mm}$. and the plate was incubated at room temperature for 18 hours. The cleared zone ring diameter that has been developed was measured in $\mathrm{mm}$. The concentration of the standard was plotted on the logarithmic axis against the corresponding cleared zones diameter on the linear axis of the semi-logarithmic graph. The diameter of the sample was plotted against the standard for obtaining the lysozyme concentration in $\mu \mathrm{g} / \mathrm{ml}$. 


\section{Bacterial infection}

Infection challenge was induced in the fish (30 fish / treatment) with two species of pathogenic bacteria Aeromonas hydrophila. Aeromonas hydrophila had grown at $25^{\circ} \mathrm{C}$ overnight in TSB medium (Himedia, Mumbai, IN) and the concentration was adjusted to $1 \times 10^{6} \mathrm{CFU} / \mathrm{ml}$ in PBS. The experimental treatments were injected with $0.2 \mathrm{ml}$ of the bacterial suspension intra-peritoneally (I.P.).

\section{Mortality percent and relative level of protection (RLP)}

The mortality rates of the challenged fish treatments were recorded daily for up to 7 days; while, feeding the previously mentioned experimental diets. The survival rates and the relative level of protection (RLP) of Nile tilapia was calculated according to (Amend, 1981).

\section{Statistical analysis}

The data were analyzed by using the GLM procedure with Two-way analysis of variance (SAS, 2009), differences among means were tested for significance according to Duncan's multiple range test (Duncan, 1955). The following model was used to analyze the obtained data:

$$
Y_{i j k}=u+T_{i}+L_{j}+\left(T_{i} x L_{j}\right)_{i j}+e_{i j k}
$$

Where:

$\mathrm{Y}_{\mathrm{ijk}}=$ observation,

$\mathrm{U}=$ the overall mean,

$\mathrm{T}_{\mathrm{i}}=$ Effect of Treatment,

$\mathrm{L}_{\mathrm{j}}=$ Effect of Concentration,

$\left(T_{\mathrm{i}} \times L_{j}\right)_{i j}=$ Interaction between Treatment and Concentration $\mathrm{e}_{\mathrm{ijk}}=$ random error.

\section{Results and Discussions}

Table (4) showed that the highest Final weight (47.76 g) and Average Daily Gain, ADG (0.38 g / day) were recorded in $\mathrm{T}_{3}$ (Azolla, $5 \%$ ) and, followed by $\mathrm{T}_{4}, \mathrm{~T}_{5}, \mathrm{~T}_{7}, \mathrm{~T}_{6}, \mathrm{~T}_{2}$ and then $\mathrm{T}_{1}$ (negative control). Many studies reported that dietary feeds which containing Azolla up to a certain level led to an improvement in growth performance, feed utilization and survival rate of Nile tilapia. For instance, Micha et al. (1988) reported highest performance in $T$. rendalli fingerlings when fed feeds incorporated with Azolla. Santiago et al. (1988) reported that, Nile tilapia fry fed rations containing up to $42 \%$ of A. pinnata outperformed fish fed a fishmeal-based control diet. In contrast, Abou Youssouf et al. (2012) 
reported that, the final mean weight of Nile tilapia decreased as Azolla inclusion level increased from $0 \%$ to $50 \%$ in the experimental diets.

Table (4). Effect of the experimental treatments on growth performances of fish.

\begin{tabular}{|l|c|c|c|}
\hline & Initial Weight (g) & Final Weight (g) & ADG (g / day) \\
\hline T1 (Control) & $30.65^{\mathrm{NS}} \pm 0.2$ & $41.39^{\mathrm{e}} \pm 0.4$ & $0.24^{\mathrm{d}} \pm 0.03$ \\
\hline T2 & $30.8 \pm 0.2$ & $41.5^{\mathrm{e}} \pm 0.4$ & $0.24^{\mathrm{d}} \pm 0.03$ \\
\hline T3 & $31.03 \pm 0.2$ & $47.76^{\mathrm{a}} \pm 0.4$ & $0.38^{\mathrm{a}} \pm 0.03$ \\
\hline T4 & $31.35 \pm 0.2$ & $44.94^{\mathrm{b}} \pm 0.4$ & $0.31^{\mathrm{b}} \pm 0.03$ \\
\hline T5 & $31.11 \pm 0.2$ & $43.3^{\mathrm{c}} \pm 0.4$ & $0.28^{\mathrm{c}} \pm 0.03$ \\
\hline T6 & $30.99 \pm 0.2$ & $42.3^{\mathrm{d}} \pm 0.4$ & $0.26^{\mathrm{cd}} \pm 0.03$ \\
\hline T7 & $31.31 \pm 0.2$ & $44.3^{\mathrm{b}} \pm 0.4$ & $0.29^{\mathrm{c}} \pm 0.03$ \\
\hline
\end{tabular}

Means in the same column having the same superscript letters are not significantly different $(\mathrm{P}<0.05)$.

Sarker et al., (2018) noticed that, when O. niloticus fish were fed with different levels of nannocholoropsis oculata (33, 66 and 100\%) it's reduce their growth performance with the increase in algae percentage in fish diets compared to control diet. Kiron et al., 2012 reported that, no reduction in weight gain of Atlantic salmon (Salmo salar) which fed an experimental diet in which whole and lipid-extracted algal meals replaced 5 or $10 \%$ of dietary protein from fishmeal.

\section{Water quality parameters}

Water quality parameters at the end of the experimental period showed no significant differences among all treatments (Figure 1). Water temperature ranged between 28.1 and $30.2{ }^{\circ} \mathrm{C}$, dissolved oxygen values were between 5.5 and $6.2 \mathrm{mg} / 1$, while its suitable level is above $5 \mathrm{mg} / 1$ (Ekubo and Abowei, 2011). pH values were between 7.2 and 7.6, while the recommended range for fish culture is between 6.7 and 9.5 according to Santhosh and Singh (2007). Unionized ammonia concentrations were between 0.01 and $0.02 \mathrm{mg} / 1$. while the maximum permissible limit is below $0.1 \mathrm{mg} / 1$, which consider safe for aquaculture as revealed by Boyd and Tucker (2012). All these values were within the acceptable ranges for fish farming. 


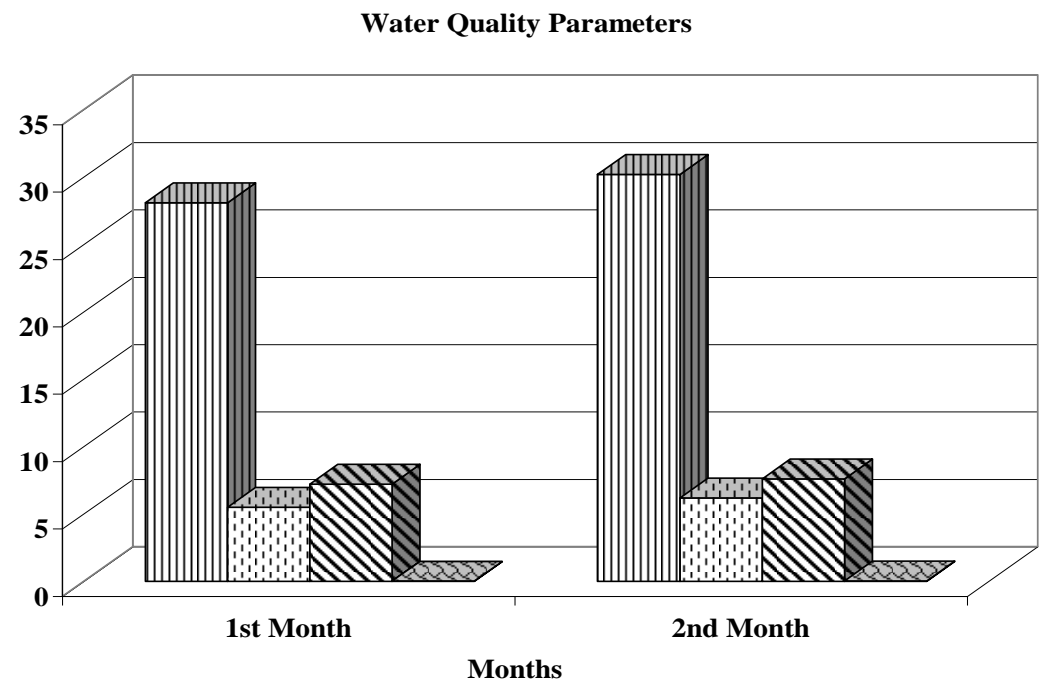

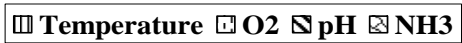

Fig. (1). Showed water quality parameters averages during the experimental period Biochemical parameters

The first sample of blood chemistry indices (after the first month) which shown in Table (5) revealed that; the highest total protein (TP) value was recorded in control and $\mathrm{T}_{2}$, while the lowest was recorded in $\mathrm{T}_{4}$. The highest albumin (Alb) value was recorded in $\mathrm{T}_{4}$ followed by $\mathrm{T}_{3}$ and $\mathrm{T}_{5}$. The highest globulin (Glob) value was acquired by the control while the lowest one was obtained by $\mathrm{T}_{6}$. All the investigated parameters were significantly $(\mathrm{P}<0.05)$ affected with the experimental treatments, except the Alb, where the treatments had no significance effect.

Table (5). Biochemical parameters of all treatments after the $1^{\text {st }}$ month.

\begin{tabular}{|l|c|c|c|}
\hline & TP $(\mathrm{g} / \mathrm{dl})$ & Alb (g / dl $)$ & Glob (g / dl) \\
\hline T1 (Control) & $5.23^{\mathrm{a}} \pm 0.024$ & $1.47^{\mathrm{NS}} \pm 0.02$ & $3.77^{\mathrm{a}} \pm 0.028$ \\
\hline T2 & $5.16^{\mathrm{a}} \pm 0.024$ & $1.46 \pm 0.02$ & $3.7^{\mathrm{a}} \pm 0.028$ \\
\hline T3 & $4.7^{\mathrm{bc}} \pm 0.024$ & $1.52 \pm 0.02$ & $3.18^{\mathrm{b}} \pm 0.028$ \\
\hline T4 & $4.33^{\mathrm{d}} \pm 0.024$ & $1.56 \pm 0.02$ & $2.87^{\mathrm{c}} \pm 0.028$ \\
\hline T5 & $4.94^{\mathrm{b}} \pm 0.024$ & $1.49 \pm 0.02$ & $3.5^{\mathrm{b}} \pm 0.028$ \\
\hline T6 & $4.5^{\mathrm{c}} \pm 0.024$ & $1.44 \pm 0.02$ & $3.07^{\mathrm{bc}} \pm 0.028$ \\
\hline T7 & $4.7^{\mathrm{bc}} \pm 0.024$ & $1.44 \pm 0.02$ & $3.26^{\mathrm{b}} \pm 0.028$ \\
\hline
\end{tabular}

Means in the same column having the same superscript letters are not significantly different $(\mathrm{P}<0.05)$.

The highest TP value was obtained by $\mathrm{T}_{4}$ and the lowest was recorded in $T_{3}$. The highest Alb value was obtained by $T_{2}$ and the lowest was in $T_{5}$ as shown in Table (6). The highest Glob value was obtained by $\mathrm{T}_{4}$ and the 
lowest was recorded in $T_{3}$. Our findings are in agreement with the findings of Mahmoud et al. (2018) who found that, total protein and albumin significantly decreased in algae treatments compared to negative control. And after infection challenge there were an increase in total protein and albumin values in algae infected treatments.

Table (6). Biochemical parameters of all treatments after the $2^{\text {nd }}$ month.

\begin{tabular}{|l|c|c|c|}
\hline & TP (g / dl $)$ & Alb $(\mathrm{g} / \mathrm{dl})$ & Glob $(\mathrm{g} / \mathrm{dl})$ \\
\hline T1 (Control) & $4.73^{\mathrm{c}} \pm 0.031$ & $1.58^{\mathrm{ab}} \pm 0.036$ & $3.15^{\mathrm{c}} \pm 0.033$ \\
\hline T2 & $4.86^{\mathrm{b}} \pm 0.031$ & $1.68^{\mathrm{a}} \pm 0.036$ & $3.18^{\mathrm{c}} \pm 0.033$ \\
\hline T3 & $4.51^{\mathrm{d}} \pm 0.031$ & $1.51^{\mathrm{b}} \pm 0.036$ & $3.09^{\mathrm{d}} \pm 0.033$ \\
\hline T4 & $5.22^{\mathrm{a}} \pm 0.031$ & $1.59^{\mathrm{a}} \pm 0.036$ & $3.63^{\mathrm{a}} \pm 0.033$ \\
\hline T5 & $4.64^{\mathrm{cd}} \pm 0.031$ & $1.46^{\mathrm{c}} \pm 0.036$ & $3.18^{\mathrm{c}} \pm 0.033$ \\
\hline T6 & $4.68^{\mathrm{cd}} \pm 0.031$ & $1.55^{\mathrm{b}} \pm 0.036$ & $3.13^{\mathrm{c}} \pm 0.033$ \\
\hline T7 & $4.91^{\mathrm{b}} \pm 0.031$ & $1.67^{\mathrm{a}} \pm 0.036$ & $3.24^{\mathrm{b}} \pm 0.033$ \\
\hline
\end{tabular}

Means in the same column having the same superscript letters are not significantly different $(\mathrm{P}<0.05)$.

\section{Antioxidant parameter}

Regarding the antioxidant results; the MDA highest values were obtained by control in both investigated periods while the lowest was obtained by $\mathrm{T}_{7}$ (Tables 7 and 8). MDA is a main product of lipid peroxidation and the increased MDA level is an important biomarker of oxidative injury (Kaya and Kaptaner, 2016). Those finding are in partial agreement with those of Mahmoud et al. (2018) who stated that, MDA of liver was higher in negative control group and infected treated with $2 \%$ algae supplement. Those findings are in disagreement with the findings of (Qiao et al., 2019) who stated that, the serum MDA content in turbot juvenile (Scophthalmus maximus L.) gradually decreased with increased dietary nannochloropsis sp. content, and values in groups $2.5,5$, and 10 $\%$ did not differ significantly (P > 0.05). The highest level of SOD in the first sampling time was obtained by control and the lowest was obtained by $\mathrm{T}_{2}$; with respect to the second sampling time the highest SOD value was in $\mathrm{T}_{6}$ and the lowest was in control. In the current study SOD and GPX activities within Nannochloropsis $s p$ treatments recorded the highest values in the middle concentration and decreased with Nannochloropsis $s p$ concentrations increased, while within Azolla treatments the highest concentration had the highest activity. Similar findings were recorded by Qiao et al. (2019) on turbot juvenile Scophthalmus maximus $L$. The same author also mentioned similar occurrences in other species such as, 
Atlantic salmon fed with N. Oceania-derived defatted meal and shrimp (Penaeus monodon) fed with the Dunaliella salina-inclusion diet.

Table (7). Antioxidant parameter of all treatments after the $1^{\text {st }}$ month.

\begin{tabular}{|l|c|c|c|c|}
\hline & $\begin{array}{c}\text { MDA } \\
(\mathbf{n m o l} / \mathbf{m l})\end{array}$ & $\begin{array}{c}\text { SOD } \\
(\mathbf{U} / \mathbf{m l})\end{array}$ & GPX (U / L) & Lysozyme \\
\hline $\begin{array}{l}\text { T1 } \\
\text { (Control) }\end{array}$ & $9.74^{\mathrm{a}} \pm 0.025$ & $5.1^{\mathrm{a}} \pm 0.027$ & $98.45^{\mathrm{e}} \pm 2.54$ & $0.44^{\mathrm{e}} \pm 0.003$ \\
\hline T2 & $9.24^{\mathrm{c}} \pm 0.03$ & $3.36^{\mathrm{d}} \pm 0.027$ & $112.7^{\mathrm{c}} \pm 2.54$ & $0.69^{\mathrm{bc}} \pm 0.003$ \\
\hline T3 & $9.58^{\mathrm{b}} \pm 0.03$ & $4.73^{\mathrm{bc}} \pm 0.027$ & $114.75^{\mathrm{b}} \pm 2.54$ & $0.89^{\mathrm{a}} \pm 0.003$ \\
\hline T4 & $9.23^{\mathrm{c}} \pm 0.03$ & $4.84^{\mathrm{b}} \pm 0.027$ & $111.85^{\mathrm{c}} \pm 2.54$ & $0.73^{\mathrm{b}} \pm 0.003$ \\
\hline T5 & $9.69^{\mathrm{ab}} \pm 0.03$ & $4.45^{\mathrm{cd}} \pm 0.027$ & $114.25^{\mathrm{b}} \pm 2.54$ & $0.64^{\mathrm{c}} \pm 0.003$ \\
\hline T6 & $9.14^{\mathrm{d}} \pm 0.03$ & $4.67^{\mathrm{c}} \pm 0.027$ & $116.8^{\mathrm{a}} \pm 2.54$ & $0.51^{\mathrm{d}} \pm 0.003$ \\
\hline T7 & $8.51^{\mathrm{e}} \pm 0.03$ & $4.63^{\mathrm{c}} \pm 0.027$ & $106.65^{\mathrm{d}} \pm 2.54$ & $0.73^{\mathrm{b}} \pm 0.003$ \\
\hline
\end{tabular}

Means in the same column having the same superscript letters are not significantly different $(\mathrm{P}<0.05)$.

As for the GPX level the control had obtained the lowest record in both sampling points while the highest record at the first month sample was obtained by $\mathrm{T}_{5}$ and the highest in the second month sample was acquired by $\mathrm{T}_{6}$. All the antioxidant parameters are statistically significant $(\mathrm{P}<$ 0.05). (Peixoto et al., 2016) stated that, Glutathione peroxidase (GPx) value in gilthead seabream (Sparus aurata) was significantly enhanced by seaweeds supplementation at 2.5, 5 and $7.5 \%$ regardless its level and the innate immune system was significantly altered by dietary seaweed supplementation at $(\mathrm{P}<0.05)$.

Table (8). Antioxidant parameter of all treatments after the $2^{\text {nd }}$ month.

\begin{tabular}{|l|c|c|c|c|}
\hline & $\begin{array}{c}\text { MDA (nmol / } \\
\mathbf{m l})\end{array}$ & $\begin{array}{c}\text { SOD }(\mathbf{U} / \\
\mathbf{m l})\end{array}$ & GPX (U / L) & Lysozyme \\
\hline $\begin{array}{l}\text { T1 } \\
\text { (Control) }\end{array}$ & $10.11^{\mathrm{a}} \pm 0.03$ & $4.33^{\mathrm{f}} \pm 0.03$ & $112.3^{\mathrm{e}} \pm 1.9$ & $0.55^{\mathrm{d}} \pm 0.006$ \\
\hline T2 & $9.06^{\mathrm{d}} \pm 0.025$ & $4.72^{\mathrm{d}} \pm 0.03$ & $119.05^{\mathrm{c}} \pm 1.9$ & $0.71^{\mathrm{c}} \pm 0.006$ \\
\hline T3 & $9.58^{\mathrm{b}} \pm 0.025$ & $4.72^{\mathrm{d}} \pm 0.03$ & $125.25^{\mathrm{bc}} \pm 1.9$ & $0.86^{\mathrm{b}} \pm 0.006$ \\
\hline T4 & $9.69^{\mathrm{a}} \pm 0.025$ & $4.93^{\mathrm{c}} \pm 0.03$ & $129.45^{\mathrm{b}} \pm 1.9$ & $1.03^{\mathrm{a}} \pm 0.006$ \\
\hline T5 & $9.51^{\mathrm{b}} \pm 0.025$ & $5^{\mathrm{b}} \pm 0.03$ & $124.1^{\mathrm{bc}} \pm 1.9$ & $0.57^{\mathrm{d}} \pm 0.006$ \\
\hline T6 & $9.15^{\mathrm{c}} \pm 0.025$ & $5.57^{\mathrm{a}} \pm 0.03$ & $140.1^{\mathrm{a}} \pm 1.9$ & $0.67^{\mathrm{cd}} \pm 0.006$ \\
\hline T7 & $8.89^{\mathrm{e}} \pm 0.025$ & $4.52^{\mathrm{e}} \pm 0.03$ & $116.4^{\mathrm{d}} \pm 1.9$ & $0.89^{\mathrm{b}} \pm 0.006$ \\
\hline
\end{tabular}

Means in the same column having the same superscript letters are not significantly different $(\mathrm{P}<0.05)$. 


\section{Lysozyme activity}

Nannochloropsis and Azolla treatments showed superior performance in term of lysozyme activities in both sampling points compared to control; the highest in the first sample was obtained by $\mathrm{T}_{3}$ while in the second sample the highest was obtained by $\mathrm{T}_{4}$ (Tables 5 and 6). Lysozyme has a tremendous importance as broad-spectrum enzyme with strong action against Gram-negative bacteria and its nutritional and physical modulation factors (Cecchini et al., 2000 Valero et al., 2014). Our findings are supported by the findings of Mahmoud $\boldsymbol{e t}$ al. (2018) who stated that, there was a significant increase in serum lysozyme activities of all treatments versus control before infection while the higher increase was recorded in phytobiotic mixture treatments post infection. Furthermore, (Peixoto et al., 2016) stated that Seabass fed dietary seaweed supplementation 2.7 up to $7.5 \%$ had increased lysozyme activity levels. Certainly, Lysozyme levels can vary considerably between different fish species and in most cases is positively correlated with disease resistance.

\section{Challenge test}

The experimental fish treatments cumulative mortality 7 days post challenge with $A$. hydrophila showed that, the maximum mortality rate (80 \%) was recorded in control compared with the other treatments, which showed (40\%) mortality in $\mathrm{T}_{5},(30 \%)$ in $\mathrm{T}_{2}, \mathrm{~T}_{6}$ and $\mathrm{T}_{7}$, while the minimum mortality value (10\%) was recorded in $\mathrm{T}_{3}$ and $\mathrm{T}_{4}$, (Figure 2 ). The current study revealed that using both Nannochloropsis and Azolla had induced significant bactericidal activity on fish in all treatments. The challenge infection revealed peak resistance of infection in $T_{3}, T_{4}$ followed by $\mathrm{T}_{2}, \mathrm{~T}_{6}, \mathrm{~T}_{7}$ and then $\mathrm{T}_{5}$, which hint an increased resistance to Aeromonas hydrophila infection. The obtained results agreed with those of (Abdel-Tawwab et al., 2009; Sharifah and Eguchi, 2011; Mahmoud et al., 2018), who stated that, significant lower mortality rate was observed in algae supplemented groups with an increased protection against microbial infection with Aeromonas hydrophila, Pseudomonas fluorescence and Vibrio anguillarum in several aquatic species in both fresh and marine water receiving algae supplemented feeds, which represented that algae had a useful impact on fish as immunostimulant. 


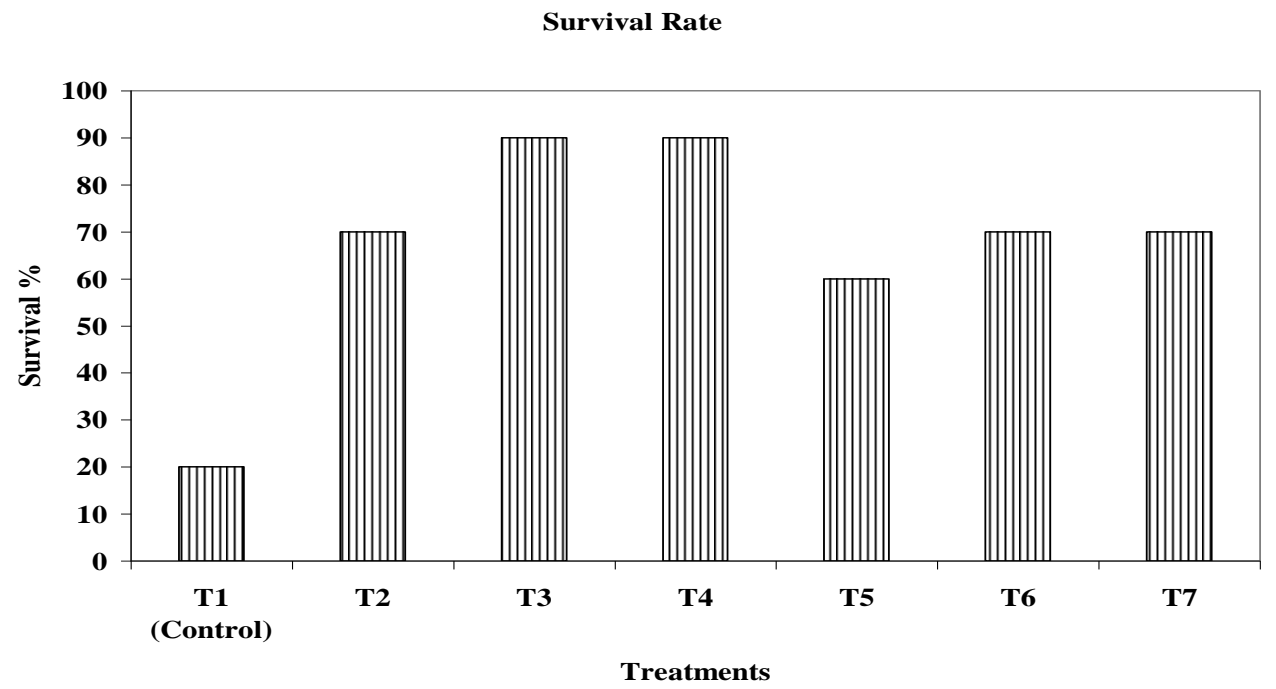

Fig. (2). Survival \% of fish in all treatments after the challenge test with $A$. hydrophila at the end of the experimental period

Those results were reflected on the RLP Values which revealed that highest value of RLP (87.5\%) was acquired by both $\mathrm{T}_{3}$ and $\mathrm{T}_{4}$ followed by $(62.5 \%)$ for $\mathrm{T}_{2}, \mathrm{~T}_{6}$ and $\mathrm{T}_{7}$; while $\mathrm{T}_{5}$ got $(50 \%)$ RLP and the least value was $(0 \%)$ for the control (Figure 3$)$.

RLP Rate

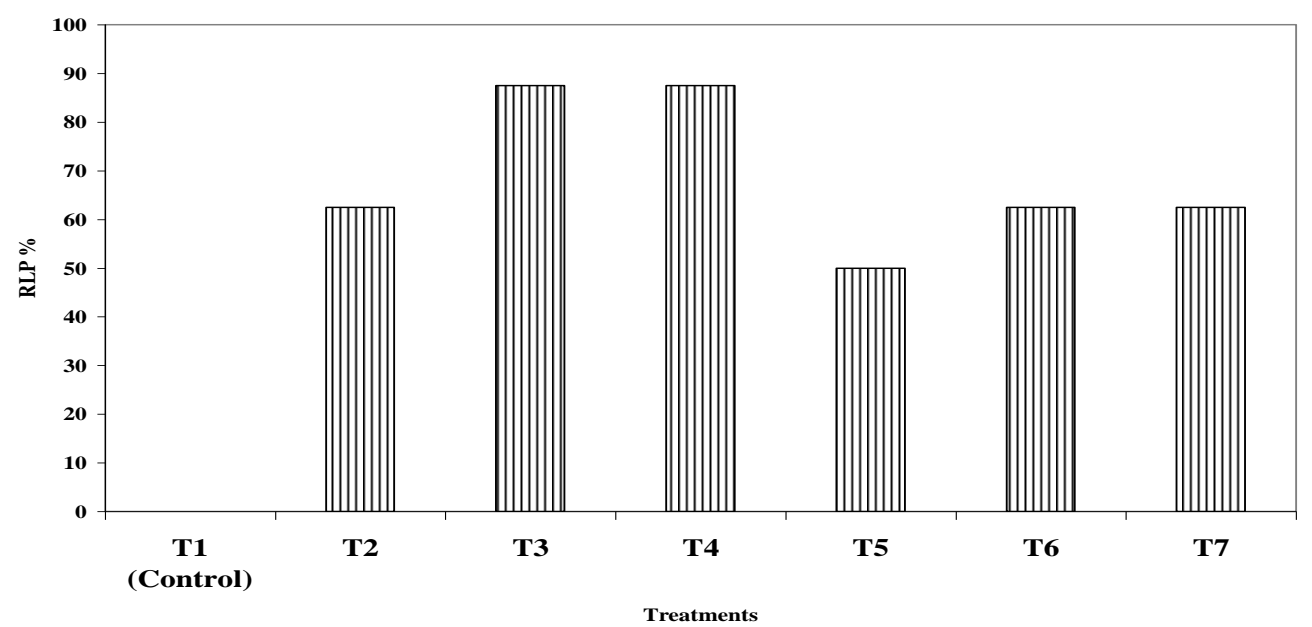

Fig. (3). Relative Level of Protection (RLP) of fish in all treatments after the challenge test with $A$. hydrophila at the end of the experimental period 


\section{Conclusion}

Addition of such natural materials (Azolla pinnata and nannocholoropsis oculata) into fish diets led to an antioxidant capacity enhancement with slight growth performance improvement and gives fish a great immunity attitude against bacterial infection and enhance survival rate.

\section{References}

Abdel-Tawwab M., Ahmad, M. H. (2009). Live Spirulina (Arthrospira platensis) as a growth and immunity promoter for Nile tilapia, Oreochromis niloticus (L.), challenged with pathogenic Aeromonas hydrophila, Aquac. Res. 40 (9) 1037-1046.

Abou, Y., Aina, M. P., Dimon, B., Fiogbé, E. D. and Micha, J. (2012). Effect of covering water surface with Azolla (Azolla filiculoides Lam.) on water quality, growth and production of Nile tilapia fed practical Azolla-diets in earthen ponds. Int J Agron Agricult Res 2: 1-9.48.

Aebi, H. (1984). Catalase in vitro, Meth. Enzymol. 105: 121-126.

Allen, M. M., Stanier, R. Y. (1968). Growth and division of some unicellular blue-green algae. J Gen Microbiol. 51:199-202; PMID:5652095

Amend, D. F. (1981). Potency testing of fish vaccines. Developments in biological

Standardization, 49: 447-454.

Anitha, K. C.; Rajeshwari, Y. B.; Prasanna, S. B.; Shilpa, S. J. (2016). Nutritive evaluation of Azolla as livestock feed. J. Exp. Biol. Agric. Sci.4, 670-674.

Anon (1988). Integralied rice-azolla-fish systems. FAO RAPA Bull.4. FAO/Regional office for Asia and the Pacific, Bangkok, Thailand.

Basak, B.; Pramanik, M. A. H.; Rahman, M. S.; Tarafdar, S. U.; Roy, B. C. (2002). Azolla (Azolla pinnata) as a Feed Ingredient in Broiler Ration. Int. J. Poult. Sci.1, 29-34.

Borowitzka, M. A. (1988). Microalgae as sources of pharmaceuticals and other biologically active compounds. Journal of Applied Phycology 4: 267-279.

Boyd, C. E. and Tucker, C. S. (2012). Pond Aquaculture Water Quality Management, Springer Science \& Business Media.

Brown, M. R., Jeffrey, S. W., Volkman, J. K. and Dunstan, G. A. (1997). Nutritional properties of microalgae for mariculture. Aquaculture 151: 315-331. 
Busher, J. T. Serum Albumin and Globulin. (1990). In: Walker HK, Hall WD, Hurst JW, editors. Clinical Methods: The History, Physical, and Laboratory Examinations. 3rd edition. Boston: Butterworths; 1990. Chapter 101.

Cagauan, A. G.; Branckaert, R. D. and Van Hove, C. (2000). Integrating fish and azolla into rice-duck farming in Asia. Naga ICLARM Q.23, 4-10.

Cagauan, A. G. and Pullin, R. S. V. (1994). Azolla in aquaculture: past, present and future, p.104-130. In J. Muir and R. J. Roberts (eds.) Recent advances in aquaculture. 5: 305.

Cecchini, S., Terova, G., Caricato, G. and Saroglia, M., (2000). Lysozyme activity in embryos and larvae of sea bass (Dicentrarchus labrax L.), spawned by broodstocks fed with vitamin $\mathrm{C}$ enriched diets. Bull Eur Ass Fish Pathol 20 (3),120-124

Cherryl, D. M.; Prasad, R. M. V.; Rao, J. S.; Jayalaxmi, P. and Kumar, D. S. (2014). A study on the nutritive value of Azolla pinnata. Livest. Res. Int. 2, 13-15.

Dahman, Y., Syed, K., Begum, S., Roy, P. and Mohtasebi, B. (2019). 14 Biofuels: Their characteristics and analysis, in: Verma, D., Fortunati, E., Jain, S., Zhang, X. (Eds.), Biomass, Biopolymer-Based Materials, and Bioenergy, Woodhead Publishing Series in Composites Science and Engineering. Woodhead Publishing, pp. 277-325.

Durmaz, Y. (2007). Vitamin E ( $\alpha$-tocopherol) production by the marine microalgae Nannochloropsis oculata (Eustigmatophyceae) in nitrogen limitation. Aquaculture 272;717-722.

Ekubo,A.A. and Abowei, J.F.N. (2011).Review of some water quality management principles in culture fisheries. Research J. Applied sciences, engineering and technology, 3:1342-1357.

El-Sayed, A. F. M. (1992). Effects of substituting fish meal with Azolla pinnata in practical diets for fingerling and adult Nile tilapia, Oreochromis niloticus L. Aquacul \& Fisheries Mgmt 23: 167-173.46.

Fiogbé, E. D.; Micha, J. C. and Van Hove, C. (2004). Use of a natural aquatic fern, Azolla microphylla, as a main component in food for the omnivorous-phytoplanktonophagous tilapia, Oreochromis niloticus L. J. Appl. Ichthyol.20, 517-520. [CrossRef]

Hoffmann, M., Marxen, K., Schulz, R. and Vanselow, K. H. (2010). TFA and EPA productivities of Nannochloropsis salina influenced by 
temperature and nitrate stimuli in turbidostatic controlled experiments. Mar.Drugs.8:2526-2545.

Howe, P.; Meyer, B.; Record, S. and Baghurst, K. (2006). Dietary intake of long-chain omega-3 polyunsaturated fatty acids: contribution of meat sources. Nutrition 22, 47- 53.

Indira, D., Sarjan, K. R., Suresh. K., Venugopal, .N and Ravi. A. (2014). Optimum conditions for culturing of Azolla. Int. J. Adv. Red. Bill. Sci. 1. 2.87.89.

Jean-Baptiste Guillerme, Céline Couteau and Laurence Coiffard, (2017). Applications for Marine Resources in Cosmetics. Cosmetics 4, 35.

Kaya, Ö. and Kaptaner, B., (2016). Antioxidant defense system parameters in isolated fish hepatocytes exposed to bisphenol A Effect of vitamin C. Acta Biologica Hungarica 67, 225-235.

Khan, M. I., Shin, J. H. and Kim, J. D. (2018). The promising future of microalgae: current status, challenges, and optimization of a sustainable and renewable industry for biofuels, feed, and other products. Microb. Cell Factories 17, 36.

Kiron, V., Phromkunthong, W., Huntley, M., Archibald, I. and De Scheemaker, G. (2012). Marine microalgae from biorefinery as a potential feed protein source for Atlantic salmon, common carp and whiteleg shrimp. Aquaculture Nutrition. 2012;18: 521-31.

Liu, C. C and Liu, X. S. (1995). A brief introduction on controlling artificial biosphere in paddy field and its new croppling system. P.343350. In J,-J. symoens and J-C. Micha (eds.) Proceeding of the Management of Integrated Freshwater Agro-piscicultural Ecosystems in Tropical Areas, Brussels. p 587.

Ma, X.-N.; Chen, T.-P.; Yang, B.; Liu, J. and Chen, F. (2016). Lipid Production from Nannochloropsis, Mar Drugs; 14(4): 61.

Ma, Y. B., Wang, Z. Y., Yu, C. J., Yin, Y. H. and Zhou, G. K. (2014). Evaluation of the potential of 9 Nannochloropsis strains for biodiesel production. Bioresour. Technol.; 167:503-509. doi: 10.1016/j.biortech.2014.06.047. [PubMed] [Cross Ref]

Mahmoud, M. M. A., El-Lamie, M. M. M., Kilany, O. E. and Dessouki, A. A., (2018). Spirulina (Arthrospira platensis) supplementation improves growth performance, feed utilization, immune response, and relieves oxidative stress in Nile tilapia (Oreochromis niloticus) challenged with Pseudomonas fluorescens. Fish Shellfish Immunol. 72, 291-300. 
Maity, J. and Patra, B. C. (2008). Effect of replacement of fishmeal by Azolla leaf meal on growth, food utilization, pancreatic protease activity and RNA/DNA ratio in the fingerlings of Labeo rohita (Ham.). Can. J. Pure Appl. Sci. 2, 323-333.

McCord, J. M. and Fridovich, I. (1969). Superoxide dismutase an enzymic function for erythrocuprein (hemocuprein), J. Biol. Chem. 244: 6049-6055.

Micha, J. C., Antoine, T., Wery, P. and Van Hove, C. (1988) Growth, ingestion capacity, comparative appetency and biochemical composition of Oreochromis niloticusand Tilapia rendalli fed with Azolla. In R.S.V. Pullin, T. Bhukaswan, K. Tonguthai, \& J. L. Maclean (Eds.), Second International Symposium on Tilapia in Aquaculture. ICLARM Conference Proceedings. Bangkok. pp: 347355.47.

Mithraja, M. J., Johnson, M., Mahesh, M., Pauland, Z. M. and Jeeva, S. (2011). Phytochemical studies on Azolla pinnata R. Br., Marsilea minutaL. and Salvinia molestaMitch. Asian Pacific J.Tropical Biomed., 1: 26-29.DOI: 10.1016/S2221-1691(11)60116-0

Mohanty, S. N. and Dash, S. P. (1995). Evaluation of Azolla caroliniana for inclusion in carp diet. J. Aquac. Trop.10, 343-354.

Ohkawa, H.; Ohishi, N.; and Yagi, K. (1979). Assay for lipid peroxides in animal tissues by thiobarbituric acid reaction, Anal. Biochem. 95: 351358.

Paglia, D. E. and Valentine, W. N. (1967). Studies on the quantitative and qualitative characterization of erythrocyte glutathione peroxidase, J. Lab. Clin. Med. 70 (1967) 158-169.

Peixoto, M. J., Salas-Leitón, E., Pereira, L. F., Queiroz, A., Magalhães, F., Pereira, R., Abreu, H., Reis, P. A., Gonçalves, J. F. M., Ozório, R. O. and de A., (2016). Role of dietary seaweed supplementation on growth performance, digestive capacity and immune and stress responsiveness in European seabass ( Dicentrarchus labrax ). Aquaculture Reports 3, 189 - 197.

Prabina, B. J. and Kumar, K. (2010). Dried Azolla as a nutritionally rich cost effective and immuno-modulatory feed supplement for broilers. Asian J. Anim. Sci. 5, 20-22.

Qiao, H., Hu, D., Ma, J., Wang, X., Wu, H. and Wang, J. (2019). Feeding effects of the microalga Nannochloropsis sp. on juvenile turbot (Scophthalmus maximus L.). Algal Res. 41, 101540. 
Rippka, R.; Deruelles, J.; Waterbury, J.B.; Herdman, M. and Stanier, R.Y. (1979). Generic assignments, strain histories and properties of pure cultures of Cyanobacteria. J. Gen. Microbiol. 111: 1-61.

Santhosh, B. and Singh, N.P. (2007). Guidelines for water quality management for fish culture in Tripura, ICAR Research Complex for NEH Region, Tripura Center, Publication no.29.

Santiago, C. B., Aldaba, M. B., Reyes, O. S. and Laron, M. A. (1988). Response of Nile tilapia (Oreochromis niloticus) fry to diets containing Azolla meal. In: The Second International Symposium for Tilapia in Aquaculture, R.S.V. Pullin, T. Bhukaswan, K. Tonguthai and J.L. Maclean, (eds.) ICLARM Conference Proceedings, Manila, Philippines. pp: 377-382.45.

Sarker, P. K, Kapuscinski, A. R, Bae, A. Y, Donaldson, E, Sitek, A. J and Fitzgerald, D. S. (2018). Towards sustainable aquafeeds: Evaluating substitution of fishmeal with lipid-extracted microalgal co-product (Nannochloropsis oculata) in diets of juvenile Nile tilapia (Oreochromis niloticus). PLoS ONE 13(7): e0201315.

SAS. (2009). Statistics. SAS Institute Inc. editors, Cary, NC.

Schltz, L. A. (1987). "Veterinary Haematology". 3rd ed., Lea and Febiger.; 39(2): 217-222.

Sharifah, E. N. and Eguchi, M. (2011). The Phytoplankton Nannochloropsis oculata Enhances the Ability of Roseobacter Clade Bacteria to Inhibit the Growth of Fish Pathogen Vibrio anguillarum. PLoS ONE 6, e26756.

Valero, Y., García-Alcázar, A., Esteban, M. A., Cuesta, A. and ChavesPozo, E., (2014). Seasonal variations of the humoral immune parameters of European sea bass (Dicentrarchus labrax L.). Fish Shellfish Immunol. 39 (2), 185-187.

Watanabe, M. M.; Kawachi, M.; Hiroki, M. and Kasai, F. (2000). NIES Collection List of Strains.SixthEdition, 2000, Microalgae and Protozoa. Microbial Culture Collections, Natio. Inst. for Envi. Stud., Tsukuba, Jap. 159.

Yaakob, Z., Ali, E., Zainal, A., Mohamad, M., and Takriff, M. S. (2014). An overview: biomolecules from microalgae for animal feed and aquaculture. Journal of Biological Research-Thessaloniki 21:6. 
تأثير الأزولا بينياتا و النانوكلوربسيس أوكيو لاتا على أداء النمو والاستجابة

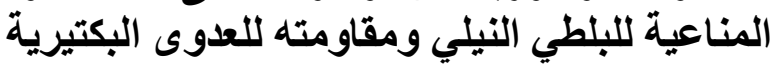

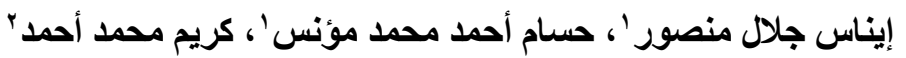

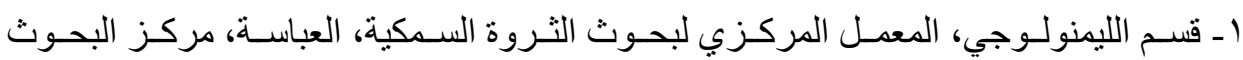

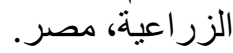

rـ شعبة إنتاج الأسماك، قسـم الإنتاج الحيو اني، كليـة الزراعـة، جامعـة عين شـس، القـاهرة،

\section{الملخص العربي}

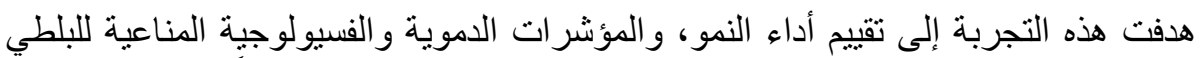

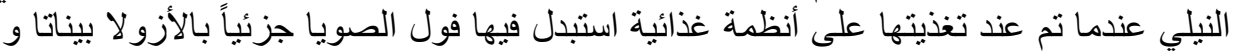

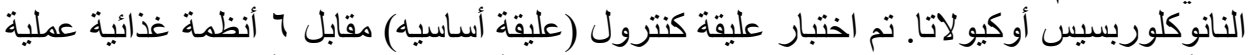

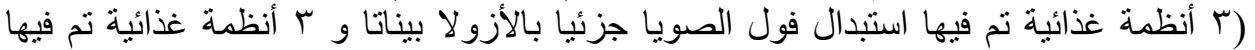

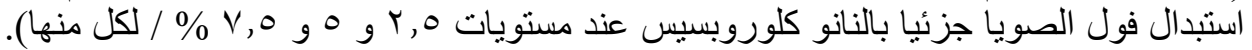

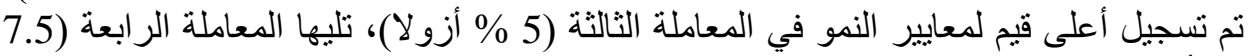

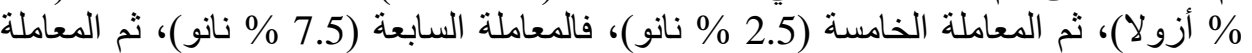

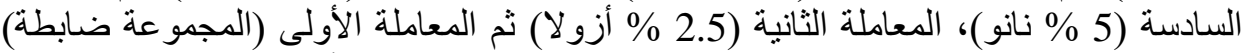

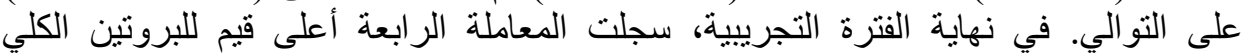

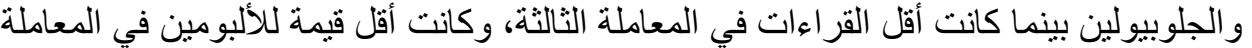

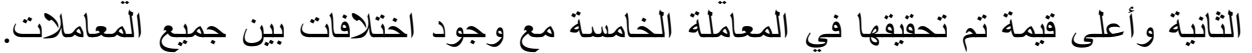

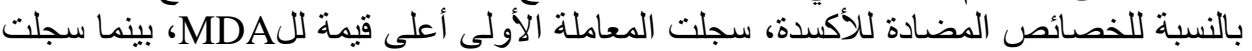

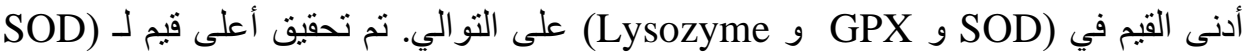

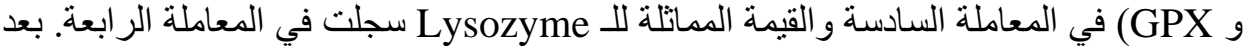

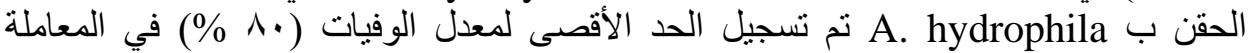

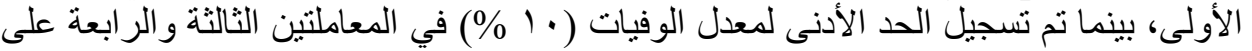

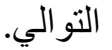

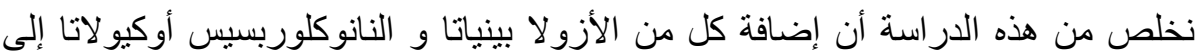

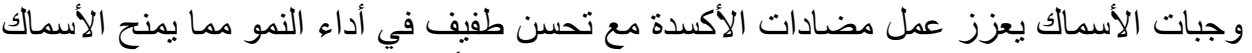
قدرة مناعيه كبيره ضد العدوى البكتيرية ويعزز معدل بقاء الأسماك على قيد الحياة. 